
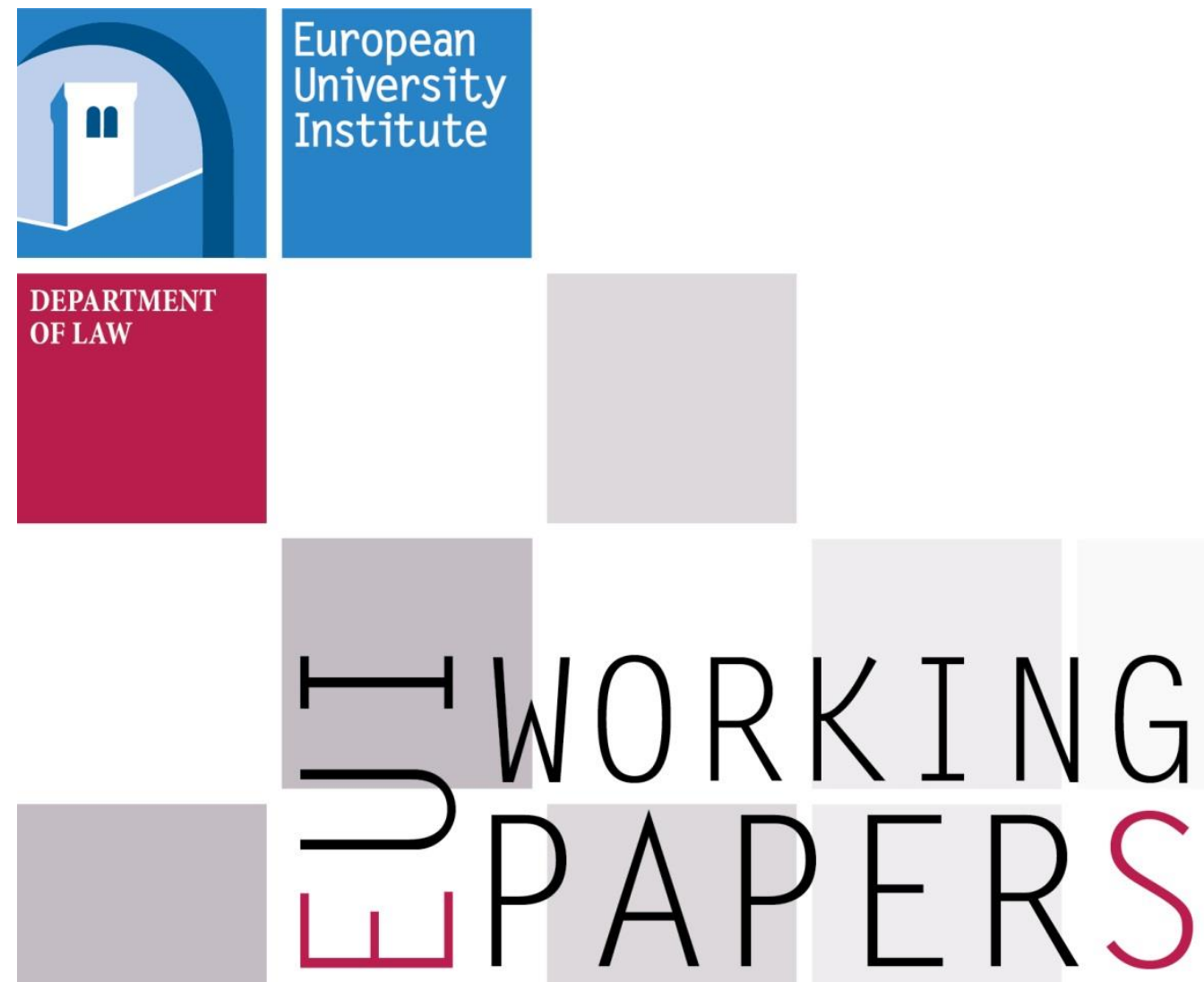

LAW 2015/09

Department of Law

European Regulatory Private Law Project (ERC-ERPL-12)

European Research Council (ERC) Grant

On the Intellectual History of Freedom of Contract and Regulation

Hans-W. Micklitz

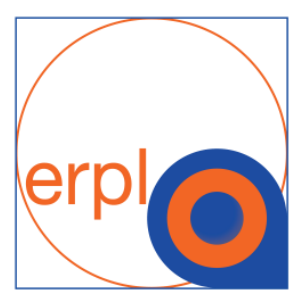



European University Institute

\section{Department of Law}

"European Regulatory Private Law" Project

European Research Council (ERC) Grant

\section{ON THE INTELLECTUAL HISTORY OF FREEDOM OF CONTRACT AND} REGULATION

Hans-W. Micklitz

EUI Working Paper LAW 2015/09

ERC-ERPL-12

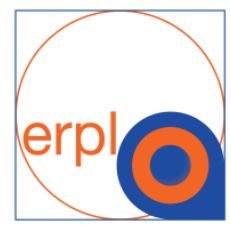


This text may be downloaded for personal research purposes only. Any additional reproduction for other purposes, whether in hard copy or electronically, requires the consent of the author(s), editor(s). If cited or quoted, reference should be made to the full name of the author(s), editor(s), the title, the working paper or other series, the year, and the publisher.

ISSN 1725-6739

(C) 2015 Hans-W. Micklitz

Printed in Italy

European University Institute

Badia Fiesolana

I-50014 San Domenico di Fiesole (FI)

Italy

www.eui.eu

cadmus.eui.eu 


\section{European Regulatory Private Law: The Transformation of European Private Law from Autonomy to Functionalism in Competition and Regulation (ERPL)}

A 60 month European Research Council grant has been awarded to Prof. Hans-Wolfgang Micklitz for the project "European Regulatory Private Law: the Transformation of European Private Law from Autonomy to Functionalism in Competition and Regulation" (ERPL).

The focus of the socio-legal project lies in the search for a normative model which could shape a selfsufficient European private legal order in its interaction with national private law systems. The project aims at a new-orientation of the structures and methods of European private law based on its transformation from autonomy to functionalism in competition and regulation. It suggests the emergence of a self-sufficient European private law, composed of three different layers (1) the sectorial substance of ERPL, (2) the general principles - provisionally termed competitive contract law - and (3) common principles of civil law. It elaborates on the interaction between ERPL and national private law systems around four normative models: (1) intrusion and substitution, (2) conflict and resistance, (3) hybridisation and (4) convergence. It analyses the new order of values, enshrined in the concept of access justice (Zugangsgerechtigkeit).

The research leading to these results has received funding from the European Research Council under the European Union's Seventh Framework Programme (FP/2007-2013) / ERC Grant Agreement n. [269722].
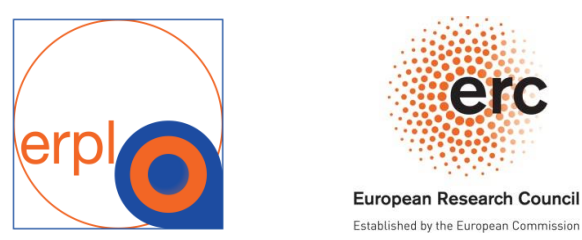
Author's Contact Details

Hans-W. Micklitz

Professor of Economic Law

European University Institute Florence, Italy

e-mail: Hans.Micklitz@eui.eu 


\begin{abstract}
Are we, private lawyers and contract lawyers, not convinced that we share a common understanding of freedom of contract, of, freedom', of ,contract', and of the restriction of freedom of contract through 'regulation'? Is this common understanding not the basis on which we all operate - implicitly or explicitly - in our intellectual discourse while cutting across different legal traditions and different legal cultures? I argue that this common understanding is no more than a rather superficial 'gentleman's agreement' which allows us to communicate with each other whilst maintaining our own preconceptions. In fact, there are different models of freedom of contract and regulation in Germany, France, the UK and the European legal order, each deeply ingrained in their respective intellectual history.
\end{abstract}

\title{
Keywords
}

Freedom of contract, regulation, legal theory, intellectual history 



\section{Table of Contents}

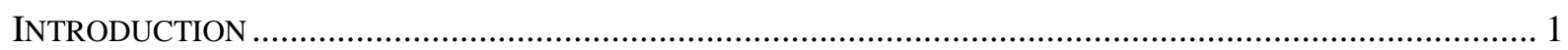

A STARTER I - ENGLISH-FRENCH DEFECTIVE SWIMMING POOLS ......................................................... 1

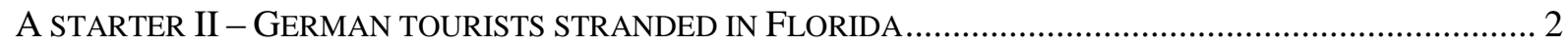

THE CONDITIONS FOR A JOURNEY INTO INTELLECTUAL HISTORY .................................................... 4

WHERE TO START WITH INTELLECTUAL HISTORY? ....................................................................... 5

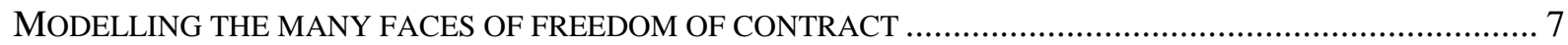

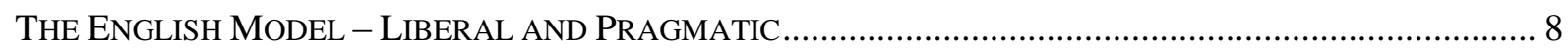

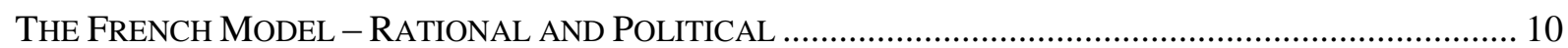

THE GERMAN MODEL - LIBERAL AND AUTHORITARIAN/PATERNALISTIC ........................................... 13

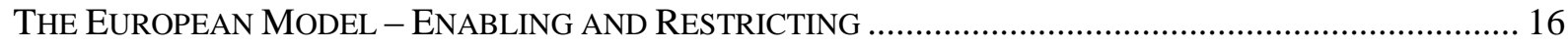

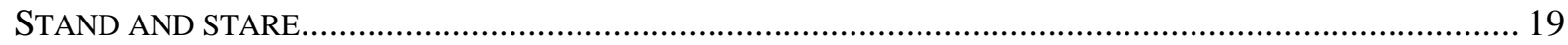




\section{Introduction}

Are we private lawyers and contract lawyers not convinced that we share a common understanding of freedom of contract, of, freedom', of, contract', of restriction of freedom of contract through 'regulation'? Is this common understanding not the basis on which we all operate implicitly or explicitly in our intellectual discourse cutting across different legal traditions and different legal cultures? $?^{3}$ At the very least, in all countries governed by a market society and even more so if the market society is embedded into the Westernised model of democracy? ${ }^{4}$

What if this common assumption turns out to be wrong or is no more than a rather superficial 'gentleman's agreement', which allows us to communicate with each other whilst maintaining our own preconceptions? Digging deeper into intellectual history, into legal theory and legal philosophy reveals that let us say that a French lawyer and an English common lawyer are not talking about the same thing, when they argue about 'freedom of contract'. This becomes even more complicated if we look at the other side of 'freedom of contract', at limitations and restrictions, at reason and coercion, ${ }^{5}$ set out via statutory regulation. We might agree on what a state is equating it with 'nation state', but we might have much more problems understanding and agreeing the meaning of 'regulation'. 'Regulation' can be private or public, if of statutory origin, it might facilitate freedom of contract or restrict it. It is statutory intervention, for good or for bad, liberal or welfarist, depending on one's perspective that might trigger very different expectations and feelings/sentiments. Our perception on 'regulation' very much depends on what we expect as citizens from 'our' state.

\section{A starter I - English-French defective swimming pools}

Let us refer as a starting point to a well-known pair of cases decided before English and French courts on a nearly identical problem. I have taken this example from Ruth Sefton-Green: ${ }^{6}$ a house owner has mandated a construction company to build a swimming pool in his garden. It turns out that the water depth does not comply with what was agreed by $22 \mathrm{~cm}$. The house owner goes to court and asks the construction company to rebuild the swimming pool. Guess in which court he gets what he wants or where he fails to obtain his desired remedy? I think if I would ask for a vote of comparative lawyers, the result might be pretty clear, maybe near to a communist voting result, 99\%. I would go even further. If consulted, non-lawyers with cross-cultural experience would come to the same result. Our preconceptions as lawyers and our cultural intuition as citizens unrelated to legal knowledge and the study of comparative law lead us to the assumption that the House of Lords ${ }^{7}$ grants compensation only

\footnotetext{
${ }^{1}$ For a German understanding, Di Fabio, Die Kultur der Freiheit, 2005.

${ }^{2}$ H. Collins Regulating Contracts, 1999, more on Regulation Theories G. Marks, L. Hooghe, and K. Blank (1996) European Integration from the 1980s: state-centric v multi-level governance. Journal of Common Market Studies 34, no. 3: 341-378

${ }^{3}$ See the writings of K. Tuori, Transnational law: on legal hybrids and legal perspectivism' Transnational Law: Rethinking European Law and Legal Thinking. Maduro, M., Tuori, K. \& Sankari, S. (eds.). Cambridge: Cambridge University Press, p. 11-57 47 p.; K. Tuori/S. Sankari (eds.), The Many Constitutions of Europe, Ashgate 2010.

${ }^{4}$ For a worldwide view G. Teubner, Contracting Worlds. The Many Autonomies of Private Law, Social and Legal Studies 9 (2000), 399, with comments by Ian Macneil, David Campbell and Oliver Gerstenberg, online http://www.jura.unifrankfurt.de/42852689/contracting_worlds.pdf

${ }^{5}$ R. Knieper, Zwang, Vernunft, Freiheit, Studien zur juristischen Konstruktion der Gesellschaft, 1981.

6 The European Union, Law and Society: Making the Societal-Cultural Difference, in Th. Wilhelmsson/E. Paunio/A. Pohjolainen (eds), Private Law and the Many Cultures of Europe, Kluwer International, 2007, 37, at 52.

${ }^{7}$ Ruxley Electronic vs. Forsyth (1996), AII ER 268.
} 
whereas the French Cour de Cassation ${ }^{8}$ obliges the construction company to rebuild the swimming pool. What kind of rationale is behind setting aside all the legal doctrinal construction that we tend to invoke? The House of Lords starts from the premise that the swimming pool is usable, though not in the envisaged way and that pecuniary damage suffices to compensate the house owner. Implicit is the idea that it does not make sense to destroy a usable swimming pool just to meet the original agreement,

a combination of pragmatic and utilitarian considerations. This will be explained as the 'English model'.

The French Cour de Cassation, however, rules exactly to the contrary. The company did not deliver on what it was supposed to do. That was the rational and the deeper 'reason'. As the water depth deviated from the promised depth, the contract was not fulfilled and the swimming pool had to be rebuilt.

The construction company bears the full costs of re-construction. Pecuniary damage does not suffice to compensate the house owner for the broken promise, or less morally and much more in the meaning of freedom of contract as expression of 'reason/raison/Vernunft' for the infringement of the commitment he has accepted. The 'reason' behind the agreement prevails over any other considerations one might and one could invoke. I look behind this rationale/reasoning when I discuss the 'French model' later on.

Comparative lawyers will know the two cases and even the cases behind the cases, ${ }^{9}$ they will find explanations related to the differences between the common law and the French Civil Code. But there is more: if a layperson comes to the same result, it tells us something about our legal consciousness, the deeper assumptions we all share about our own legal systems, on the expectations we have in the functioning of the courts and of society, for good and for bad. The Eurobarometer is a neat indicator which allows for a deeper look into these differing pre-conceptions at least between the $28 \mathrm{EU}$ Member States. ${ }^{10}$ We may now speculate on what a US court, a Canadian court, a Brazilian court, an Israeli court, a Dutch Court, an Italian Court or a German Court would have decided in a similar case. I am sure there are similar if not identical cases ${ }^{11}$ and I am equally sure that a survey of the citizens of these countries would lead to results similar to my English-French comparison. If my assumption is correct, then there must be a deeper layer of? behind the legal rules, enshrined in long grown cultures and traditions. Let me clarify already at this point that I do not argue that these layers are 'eternal' in the sense of Pierre Legrand' ${ }^{12}$ famous article that European legal cultures are not converging. I will come back to this issue at the end of my considerations.

\section{A starter II - German tourists stranded in Florida}

My second example is well-known to European lawyers, maybe less so outside of Europe. It deals with consumer law an area of law, which is seen to restrict and limit freedom of contract via statutory

\footnotetext{
${ }^{8}$ Sefton-Green refers to Civ 311 May 2005, no. 03-21136, Bull civ III no. 103, (2005) RTDCiv 596 rebuilding a house that was $33 \mathrm{~cm}$ lower than the contractual stipulations; the swimming pool counterpart, however, is Cour de Cassation, 17 November 1984, reported in H. Beale, H. Kötz, D. Tallon, Cases, Materials and Text on Contract Law, Ius Commune Series, Hart Publishing, 2002, 689-690.

${ }^{9}$ The two cases are not unique. They represent a well established and long standing doctrine, references in Sefton-Green, fn. 1; see also F. Werro, Comparative Studies in Private Law, A European Point of View, in M. Busani/Hugo Mattei (eds.), The Cambridge Companion on Comparative Law, CUP 2012 at p. 132-133.

${ }^{10} \mathrm{http} / / /$ ec.europa.eu/public_opinion/index_en.htm

${ }^{11}$ The whole Trento project - the Common Core of European Private Law - is based on the idea that the same case is looked at through the eyes of different legal orders. http://www.common-core.org/

${ }^{12}$ European Legal Systems are not Converging, International and Comparative Law Quarterly Volume 45 (1996) pp 52-81
} 
intervention. In the early 1990s, a German tourist had booked a package tour to Florida, transport, accommodation and nutrition, all inclusive at incredibly favourable prices - two weeks for 500 or 600 German marks, roughly 250-300 Euro. Hundreds of German travellers availed of the offer. But - que sera sera. A group of German consumers were caught by surprise by the bankruptcy of the tour operator. In 1993, they found themselves stranded in Florida. The operator could not bring them home and they had to buy tickets to return to Germany.

The legal outcome is well-known. Germany had not implemented in time Directive 90/314/EEC on package tours. This Directive had obliged Member States to shield consumers against the bankruptcy of tour operators, shifting the risk of default from the individual traveller to the community of travellers. The risk is thereby socialised, as all potential travellers have to cover the costs for a fund the tour operator provides. ${ }^{13}$ With reference to the Francovich ${ }^{14}$ doctrine, the stranded consumers sued the German state for non-compliance with EU law requirements, namely, the delayed transposition of the Directive. They asked for compensation or restitution of the costs of their return ticket. The Court of Justice of the European Union confirmed in Dillenkofer ${ }^{15}$ the liability of the German State. This was a costly lesson for the German state which had to pay roughly 20 Million German Marks or 10 Million Euro. Consumer organisations and consumer victims celebrated the judgment as a great success.

The societal deeper dimension behind the conflict is of more interest here. Around the time of the conflictual debate on who should bear the costs of the stranded consumers, a German TV invited several of the stranded travellers and a special guest to a talk show. The special guest was an American,

a consumer lawyer. The German consumers were given the opportunity to tell their stories. Many of them went to the German Embassy asking for financial support as it turned out that a single return ticket was 3 or 4 times more expensive than the price for the package tour. At some point the American lawyer spoke up and addressed a simple question to the stranded travellers and the TV community: why did you not chartered a plane, addressing both the class of stranded consumers and the German Embassy? He suggested that it would have been much less expensive for the stranded travellers or for Germany.

The simple question brings to light the expectations of German citizens, first the expectation that the economically highly doubtful deal of two weeks holidays in Florida for 500 - 600 German Marks is to be realised. They trusted the contract - a deal is a deal. Maybe subconsciously they were also convinced that the German state would get them out, if the contractual expectations turned out to be wrong.

Would Greek consumers or French consumers have had the same expectations of their contract with a package tour operator and of their state? Would they have behaved in the same way? Would they have also bombarded their embassies with complaints and expectations or would they have chartered a plane? What about American citizens flying to Europe who become stranding there? Would they have chartered a plane or would they have employed an American lawyer to fly to Europe and launch a class action?

I assume that the expectations differ considerably.

However, there is more at stake than human help provided by national embassies for stranded citizens. EU law equips all EU citizens with individually enforceable rights to claim from their state to pay for the transfer, provided the respective state has not implemented or not correctly implemented the

\footnotetext{
${ }^{13}$ Article 7 Directive 90/314/EEC provides for different models see St. Weatherill, EU Consumer Law and Policy, Elgar 2005, 98-101; comprehensively, K. Tonner, Zivilrecht unter europäischem Einfluss: Die richtlinienkonforme Auslegung des BGB und anderer Gesetze - Erläuterungen der wichtigsten EG-Verordnungen (Herausgeber Gebauer/Wiedmann), Richard Boorberg Verlag, Stuttgart [u.a.], Kommentierung des Kapitel 13: Reisevertrag, 2. Auflage 2010.

${ }^{14}$ ECJ Andrea Francovich and Danila Bonifaci and others v Italian Republic v. Pretura di Vicenza and Pretura di Bassano del Grappa - Italy; Joined cases C-6/90 and C-9/90, ECR 1991 I-05357.

${ }^{15}$ ECJ, Case C-178/94, C-179/94, C-188/94, C-189/94 und C-190/94, ECR 1996 I-4845.
} 
Directive on package tours. What is happening here? It is not that the Member States accepted liability voluntarily. It is the EU via the CJEU which had imposed it on the Member States. The individual enforceable rights are granted to all EU citizens, formally in their own right but substantively EU citizens are instrumentalised to guarantee the uniform application of EU law in the Member States. Thus, regulation of package tours via the EU does not only set boundaries to the freedom of package tour operators it also paves the way for more entrepreneurial freedom in a European market.

\section{The conditions for a journey into intellectual history}

I would like to take you with me on a journey to search for the reasons behind these preconceptions ${ }^{16}$ and the deeper layers of what shapes our preconceptions. However, as my knowledge of the differences between legal orders is rather limited - I would claim to half a solid understanding of the French,

the English, the American and the Italian legal order, let alone the one in which I was trained. I will take the German, the French, the UK and the EU legal order as a starting point to look for and to identify the deeper layers of freedom of contract. There is a word needed on what I understand by 'knowledge',

in particular in times where comparative legal methodology is in a state of crisis. ${ }^{17}$ When I was educated in comparative legal research in the 1970s and 1980s, the thinking in Europe still followed the ground breaking work of Zweigert/Kötz's Introduction to Comparative Law ${ }^{18}$ so wonderfully translated

the late Tony Weir. ${ }^{19}$ Legal systems were grouped around 'legal families', mainly the four European families, the Romanic, the Germanic, the common law and the Nordic Countries, sharing a common European culture, the Roman law and the Christian canon law. ${ }^{20}$ The method applied was functional comparison, looking for the 'best solution', meaning the solution which fits best into the differing traditions of the states. What is more important here was the pedagogical message inherent to the idea of legal families. Engaging in comparative law and comparative legal method requires first and foremost knowledge of the language, but even deeper knowledge of the country, of the deeper layers of the respective societies. This kind of knowledge, however, had to be gained via training and education in the country itself. In that spirit, I benefitted from the opportunity to study law in Switzerland (the French speaking part), in France, in the UK, in the US and latterly in Italy. Today this sounds old-fashioned, as comparative lawyers have to be engaged in the comparison of countries and legal systems where they know neither the language nor the country's history/culture(?). The EU promoted this kind of approach through its ever stronger insistence on 'inclusion', meaning not following the legal families, but covering the legal orders of 28 Member States. This leads to comparison via tables. I admit that I was involved in that approach. Interestingly enough, Legal origin

${ }^{16}$ On preconceptions, J. Esser, Vorverständnis und Methodenwahl in der Rechtsfinding, Athenäum, Frankfurt 1970, unfortunately this book has never been translated into English. Only an Italian version is available.

${ }^{17}$ At least in Europe there is a whole wave of publications discussing private law: it is hard to do justice to all those who are writing on this. It might suffice to refer to The Oxford Handbook of Comparative Law, Edited by Mathias Reimann and Reinhard Zimmermann, OUP 2006, published online 2012 and the Elgar Encyclopedia Of Comparative Law, Edited by Jan M. Smits, 2006, paperback 2008. However, they all share a common concern. The old and established methodology of Zweigert/Kötz (see below) does no longer suffice to handle the ever bigger complexity of comparative law in a globalized world.

${ }^{18}$ First version, Einführung in die Rechtsvergleichung, 1. Auflage 1971, last version in English, K Zweigert/H Kötz Introduction to Comparative Law, $3^{\text {rd }}$ edition 1998

${ }^{19}$ See Tony Weir, On the Case, Hart Publishing, 2012.

${ }^{20}$ F. Wieacker, Voraussetzungen europäischer Rechtskultur Verlag Göttinger Tageblatt,1985, ins Englische übersetzt von Edgar Bodenheimer unter dem Titel ,Foundations of European Legal Culture, The American Journal of Comparative law 38 (1990), 1-29 
theory (LOT) took the legal families approach seriously, ${ }^{21}$ which could have reinvigorated the Zweigert/Kötz approach. However, what really happened is that LOT revealed the weakness of thinking in families as it cannot do justice to the deeper traditions and cultures of the countries compared. $R$. Michaels labelled LOT 'comparison in numbers', 22 trying to understand why comparative lawyers remained so speechless in their reaction and did not defend the functional method.

However, the purpose of this paper is not to speculate on the future of comparative law as a legal method, all that I want is to take you with me on a journey of intellectual history, legal theory, a little bit of legal philosophy, methodologically speaking, into identifying the dominating 'Rechtsbewußtsein'

the legal conscience. ${ }^{23}$ My considerations in this paper are built on previous research on the many concepts of social justice in private law $^{24}$ and the (un)systematics of European legal culture, ${ }^{25}$ where I have tried to understand, to reveal and to model the deeper intellectual history and culture, at least with regard to France, Germany, the UK and the European Union. What I am doing here is to use this research and the arguments developed in order to transpose them to my question on the deeper layers of 'freedom of contract'. I am fully aware that modelling by country is risky and that it might look as if traditions and cultures are not subject to political, economic and social change. ${ }^{26}$ I would defend, nevertheless,

the idea that such grouping around models is useful in identifying differences and maybe in deepening our mutual understanding.

\section{Where to start with intellectual history?}

Where does one start with the intellectual history of freedom of contract and regulation? For freedom contract it should be the Roman law. Here we are on save historical ground. We can refer to the foundations of Roman law and how these foundations survived the last 2000 years not only in continental law, but also in the common law countries. ${ }^{27}$ However, the ground might be less stable and

\footnotetext{
${ }^{21}$ For an analysis of the different strains of LOT S. Deakin/K. Pistor (eds), Legal Origin Theory Edward Elgar 2012

${ }^{22}$ R. Michaels, Comparative Law by Numbers? Legal Origins Thesis, Doing Business Reports, and the Silence of Traditional Comparative Law, AJCL 2009, 765; M. Siems, Comparative Law, CUP 2014.

${ }^{23}$ U. Raulff (ed.), Mentalitätsgeschichte. Zur Historischen Rekonstruktion geistiger Prozesse, 1987; Schulze, H. (1985), 'Mentalitätsgeschichte - Chancen und Risiken eines Paradigmas der französischen Geschichtswissenschaft', Geschichte in Wissenschaft und Unterricht, 36, 247-270; D. Kennedy, (2006), 'Three Globalizations of Law and Legal Thought: 1850-2000', same author, The Rule of Law, Political Choices and Developing Common Sense both published in D. Trubek/A. Santos (eds), The New Law and Economic Development, Cambridge University Press, 2006, p. 19 and p. 95. In a European historical perspective S. Conrad/S. Randeria Geteilte Geschichten. Europa in einer postkolonialen Welt in the S. Conrad/S. Randeria (eds), Jenseits des Eurozentrismus. Postkoloniale Perspektiven in den Geschichts- und Kulturwissenschaften, Frankfurt Campus, 2002, 9-49.

${ }^{24}$ H.-W. Micklitz (ed.), The Many Concepts of Social Justice in European Private Law, Elgar 2011

${ }^{25}$ The (Un)-Systematics of (private) Law as an Element of European Legal Culture, in Genevieve Helleringer/Kai Purnhagen (eds.), Towards a European Legal Culture, München/Oxford/Baden-Baden, Beck/Hart/Nomos, 2014, 81-115

${ }^{26}$ Think of Hall/Soskice, P.A. Hall/D. Soskice, An Introduction to Varities of Capitalism, from same authors (eds), Varities of Capitalism - The Institutional Foundations of Comparative Advantage, 2001, 1, for a stock taking of the debate, D. Bohle/B. Greskovits, Varities of Capitalism Tout Court, European Journal of Sociology 50 December 2009, pp 355, for a strong critique voiced by W. Streek Re-forming Capitalism, Institutional Change in the German German Political Economy, 2009, 251, wo claims that the VoC neglects the two major driving forces of change in capitalist societies 'fear' (of the workers) and 'greed' (of the entrepreneurs).

${ }^{27}$ R. Zimmermann „Heard melodies are sweet, but those unheard are sweeter ...“ Condicio tacita, implied conditions und die Fortbildung des europäischen Vertragsrechts, Archiv für civilistische Praxis 193 (1993), 121
} 
less safe than its promoters pretend. ${ }^{28}$ Regulation is much more complicated. It is obvious that the Roman Empire used - what we call today 'regulation' - to govern - what would be called today the 'economy'. However, it might suffice to recall that nowadays we associate 'regulation' with the existence of a state and a territory. This brings us to the Peace of Westphalian, concluded in 1648, in which the foundations of what later became the nation state were laid.

In private law more broadly which includes freedom of contract, the benchmark for the beginning or the reinvigoration of Roman law is fixed to the foundation of the University of Bologna around $1130 / 1140^{29}$ and the scholastic school of law. Following Berman, ${ }^{30}$ the starting point for the reestablishment

of Roman law, private law and contract law, is the conflict between the Catholic Church (the spiritual power) and the Emperor (the temporal power) which culminated in the conflict between Pope Gregory VII and Emperor Henry IV over the independence of the Church from the temporal power. Berman argues that the separation of spiritual and temporal power did not only initiate early state building, first of the Church and then the Emperor paving the way for the development of the nation state after the religious wars in the $16^{\text {th }}$ and $17^{\text {th }}$ century, but also the scholastic school of law in Bologna first and then elsewhere in Europe. ${ }^{31}$ The Crusades between the $11^{\text {th }}$ and the $13^{\text {th }}$ century led to a much stronger exchange between the West and the East, intellectual exchange via the reinvigoration of the old Greek and Roman philosophy, but also commercial exchange which went hand-in-hand with the Crusades. Hence, there is a link between the rediscovery of the Roman law, the split of spiritual and temporal power and the Crusades, which strongly underpins the need to locate the intellectual history of Western law(?) to that epoque. One might equally argue that the starting point of my undertaking could and should be the discovery of the Americas in the $15^{\text {th }}$ century and the growing conflicts between the Spanish and the English empires, without which the deeper intellectual history of the United States cannot be fully understood. The new strand of research initiated by Thomas Duve, ${ }^{32}$ the Director of the Max-Planck-Institut at Frankfurt am Main, emphasizes the links, interaction and interchange, culturally, politically and economically, between Europe and the 'new World', the two Americas. I will not go back that far.

My approach is more modest and it is more closely tied to my European cultural roots, to the younger history of codified continental law and the then established role of the state in the economy and society. This paper owes its origins to an invitation to speak on social justice at the University of Sorbonne, Paris. Thinking about 'justice' in such an environment must coincide - at least this is what I am convinced of - with an analysis of the links between state-building and constitution-building, as well as private legal order building and codification. Whilst such a starting point offers joint perspectives in comparing France and Germany, it fell short by not taking the United Kingdom into account.

If anything, a parallel may be drawn between the French Revolution of the late $18^{\text {th }}$ century and

\footnotetext{
${ }^{28}$ Much more nuanced in particular with regard to the transfer and re-transfer of laws between European countries and what became later their colonies, Th. Duve, Von der Europäischen Rechtsgeschichte zu einer Rechtsgeschichte Europas in globalhistorischer Perspektive, Max Planck Institute for European Legal History research paper series, No. 2012/01, shortened version in English European Legal History Global Perspectives Max Planck Institute for European Legal History, research paper series No. 2013-06.

${ }^{29}$ Founded in 1088, but the charter came later in 1156, W. Rüegg, Geschichte der Universität in Europa. Bd. 1. München 1993

${ }^{30}$ H. J. Berman, Recht und Revolution. Die Bildung der westlichen Rechtstradition, Frankfurt 2001, p. 144 et seq.

${ }^{31}$ H. J. Berman, Recht und Revolution. Die Bildung der westlichen Rechtstradition, Frankfurt 2001, p. 146 and p. 215.

32 See references above and in particular the documentation of the inauguration of the new buildings of the Institute, Rechtsgeschichte, Legal History, Journal for the Max Planck Institute für European Legal History, RG (22) 2014, 394 pages.
} 
German state-building of the 19th century on the one hand, with the Civil war and the conflict between the English Crown and Oliver Cromwell in the 17th century on the other. This is roughly the period I investigated in attempting to explain where the different patterns of freedom of social justice derive from. I use these findings in my attempt to transfer them an understanding of the deeper layers of freedom of contract.

\section{Modelling the many faces of freedom of contract}

The table labels the particular understanding of freedom of contract and regulation, rooted in intellectual history. In the following, I will explain the categorisation for the four countries under investigation and the European Union, ${ }^{33}$ and provide a rough account of the socio-economic and political background to the different models of autonomy and regulation in the three countries and the European union, thereby elaborating the characteristics of the many faces of freedom of contract in a bottom-up perspective.

\footnotetext{
${ }^{33}$ The following analysis is a developed an adjusted version of H.-W. Micklitz, The (Un)-Systematics of (private) Law as an Element of European Legal Culture, in Gene-vieve Helleringer/Kai Purnhagen (eds.), Towards a European Legal Culture, München/Oxford/Baden-Baden, Beck/Hart/Nomos, 2014, 81-115
} 


\begin{tabular}{|l|l|l|l|}
\hline \multicolumn{1}{|c|}{ Country } & $\begin{array}{l}\text { Model of freedom } \\
\text { of contract }\end{array}$ & Intellectual history & \multicolumn{1}{|c|}{ Regulation } \\
\hline France & $\begin{array}{l}\text { A political project } \\
\text { Code Civil }\end{array}$ & $\begin{array}{l}\text { French rationalism } \\
\text { Enlightenment }\end{array}$ & $\begin{array}{l}\text { Regulating contracts } \\
\text { as a political } \\
\text { counter-project }\end{array}$ \\
\hline Germany & $\begin{array}{l}\text { A liberal } \\
\text { authoritarian/ } \\
\text { paternalistic project } \\
\text { Bürgerliches } \\
\text { Gesetzbuch }\end{array}$ & $\begin{array}{l}\text { German idealism } \\
\text { Metaphysics }\end{array}$ & $\begin{array}{l}\text { Regulating contracts } \\
\text { as a technical } \\
\text { bureaucratic exercise }\end{array}$ \\
\hline United Kingdom & $\begin{array}{l}\text { A liberal pragmatic } \\
\text { project } \\
\text { Common law }\end{array}$ & $\begin{array}{l}\text { Empiricism and } \\
\text { Utilitarianism } \\
\text { Pragmatism }\end{array}$ & $\begin{array}{l}\text { Regulating contracts } \\
\text { to solve 'concrete } \\
\text { Problems' }\end{array}$ \\
\hline European Union & $\begin{array}{l}\text { A technocratic } \\
\text { project } \\
\text { Regulatory private } \\
\text { law }\end{array}$ & $\begin{array}{l}\text { Instrumentalism and } \\
\text { functionalism }\end{array}$ & $\begin{array}{l}\text { Regulated freedom - } \\
\text { enabling and shaping } \\
\text { autonomy }\end{array}$ \\
\hline
\end{tabular}

\section{The English Model - Liberal and Pragmatic}

In English history there is no comparable event to the adoption of the Civil Code in France or in Germany. The civil war took place in the $17^{\text {th }}$ century and led to major changes in society and in the parliamentarian system. But, it neither yielded a constitution nor a coherent codified body of civil law, rather, it made way for the Declaration of the Bill of Rights in 1689. The French and the German legal systems, seen through the eyes of a common law lawyer (daring to suggest that this is possible for me, a civil law lawyer) share a relatively homogenous view on the role and function of freedom of contract in society. They are united in the idea of universal values that infiltrate legal principles and concepts. 'Autonomy' or 'autonomie' belongs to the core of these values. This is exactly where common lawyers run into difficulties. ${ }^{34}$

Therefore, the true difference between continental law and common law must be deeper and the reasons must date further back than the French revolution. The break-even point from which the continental legal and the common law system diverged in following different paths had to be identified. I tied my considerations to the clash between different philosophies, to the remaining influence of the scholastic in continental Europe and to its growing critique through nominalism in the UK. This was also around the time when the relative cultural unity of Europe during medieval times broke into pieces. ${ }^{35}$ I think it is empiricism which is responsible for the deep differences between continental and common law legal systems. Despite the strong intellectual exchange in particular between France and England, Hobbes imported ideas from France, Rousseau referred to John Locke, the ideas and concepts of Francis Bacon's empiricism became prevalent after the failure of Cromwell. Empiricism paved the way for utilitarianism - and here we have the key to understanding the English reservations against regulatory intervention into the economy, but also the explanation for the typical

\footnotetext{
${ }^{34}$ Lord R. Goff (1997), 'The Future of the Common Law', International and Comparative Law Quarterly, 46 (4), 745

${ }^{35}$ H.J. Berman, Recht und Revolution. Die Bildung der westlichen Rechtstradition, Frankfurt, 2001 p.265.
} 
English pragmatism ${ }^{36}$ which allows for regulatory intervention, in case there is a concrete need for action.

Both historical strings tied together justify my assumption that the continental European understanding of freedom of contract does not comply with philosophical, historical, economic and legal structures in England or - to put it the other way round - that England has paved the way for a legal system which is deeply rooted in nominalistic and utilitarian thinking. Freedom of contract lies at the crossroads of these deep roots in English intellectual history. Nominalism served to cut away the ideological barriers enshrined in the scholastic school of law, to free English contract law from the Pandectist heritage, utilitarianism went hand in hand with the rise of the English 'trading state' (Handelsstaat) which has its origins in the $19^{\text {th }}$ century. ${ }^{37}$ Contracting and contract law, the freedom of commerce, the freedom to conclude contracts, this is where the heart of English contract law lies. Freedom of contract, therefore, means first and foremost the economic freedom to voluntarily engage in economic transactions without any risk of statutory interferences, with the exception of paying taxes to the Crown. ${ }^{38}$

In this way, the English way of viewing the role and function of contract law is much more economic (ökonomischer) in its basic assumptions as opposed to German Idealism (Kant, Fichte, Hegel, Schelling) or French Rationalism (Descartes, Pascal, Voltaire, Rousseau). It is a 'shorter way' from 'utility' to economic efficiency and economic effectiveness than from duty, reason, will or spirit (Pflicht, Vernunft, Wille, Verstand, Geist). It can be much more easily adapted to European 'Integration through Law, ${ }^{39}$ where judges and the judicial system are given a major role in the realization of the Internal Market. ${ }^{40}$

What is the relationship between the particular English variant of freedom of contract and English legal culture? The English state is a liberal state. Its function is not to control the economic behavior but to guarantee freedom of contract first for the merchant adventurer in the 17th century, today for the business environment at large. ${ }^{41}$ Statutory intervention into the economy is feasible if there is a political need. Labour law legislation and consumer law legislation provide ample evidence for such an approach. The UK legislator was at the forefront of consumer legislation, with regard to consumer credit and to consumer safety the UK legislator has long set the benchmark for statutory intervention. Pragmatism guides statutory regulation via the legislator when comes to restrict the freedom to contract.

${ }^{36}$ Lord R. Goff (1997), 'The Future of the Common Law', International and Comparative Law Quarterly, 46 (4), 745 ; Markesinis, B.S. (1994), 'Learning from Europe and Learning in Europe', in B. S. Markesinis (ed.), The Gradual Convergence: Foreign Ideas, Foreign Influences and English Law on the Eve of the $21^{\text {st }}$ Century, p. 1; Koopmans, T. (1991), 'The Birth of European Law at the Cross Roads of Legal Traditions', The American Journal of Comparative Law, $39(3), 493$.

${ }^{37}$ O. Holmes, The Common Law, 1909, online http://www.gutenberg.org/files/2449/2449-h/2449-h.htm

${ }^{38}$ Henry James, The Rise and the Fall of British Empire, first published 1994.

39 M. Cappelletti/M. Seccombe/J. Weiler, Integration Through Law: Europe and the American Federal Experience, M. Cappelletti/M. Seccombe/J. Weiler (eds.), Integration Through Law, Volume 1, Book 1, 1986, 3-68; D. Augenstein (ed.) 'Integration through Law' Revisited: The Making of the European Polity, Ashgate 2011.

${ }^{40}$ No research has been undertaken as to whether there is a link between the adherence of the UK to the EU and the deepening of European integration via case-law. Whilst the building blocks van Gend en Loos as well as Costa Enel had been decided before the UK joined the EU, the ground breaking judgment Dassonville and Cassis de Dijon which paved the way for the development of the Internal Market were taken with participation of UK judges. Today's pattern of integration might have changed. Ch. Joerges, even speaks of 'integration without law' referring to the dominance of politics and the influential role of 'governance'.

41 Atiyah's Decline and Fall of Freedom of Contract, or Ibbetson's History of Obligations show that the real turning point was between 1790 and 1830, when the last remnants of just price were stripped away. 
This can be felt until today in the way in which the transposition of European consumer law directives are integrated or not into the English system. Directive 99/44/EC might serve as an example. The UK legislator rejected any attempt for a major revision of the English law on contracts, which would have challenged the foundations of freedom of contract and preferred to adopt a separate piece of law which stands side-by-side with the common law on contract on the one hand, and the Sale of Goods Act on the other. ${ }^{42}$ A similar continuity can be demonstrated in the recent decisions of the House of Lords as it then was on the control of unfair contract terms in consumer contracts under EU Directive 93/13/EEC. This piece of EU law has led to irritation in the English system as it submits standard terms to a general fairness test, an approach which runs counter to the leading ideology of the English legislator, ${ }^{43}$ where regulatory intervention should be targeted to concrete problem solving, but not to reverse the supreme position of freedom of contract. ${ }^{44}$

The basic formula which lies at the heart of the English legal culture can be condensed in one single formula - what is useful is right. Here nominalism, empiricism and utilitarianism come together. Freedom of contract is foundational to common law on contracts, statutory intervention is acceptable as long as it aims at solving concrete consumer or labour concerns.

\section{The French Model - Rational and Political}

France has a particular standing in the legal and theoretical discourse on the interrelationship between constitution-building and private legal order-making. It follows from the French revolution, the results of which are still today stamping our understanding of ' $a$ ' constitution, ' $a$ ' civil code, a 'contract', a 'tort'. The key events in France took place in the space of two decades, contrary to England where no such clear cut events, at least not with regard to constitution-building and private legal ordermaking, can be fixed. The French Revolution led to a break ${ }^{45}$ with feudalistic structures and instituted a bourgeois society governed by individual freedom and equality of rights that became even more visible in the Code Civil and in the French Constitution. ${ }^{46}$ Its legacy can easily be traced in the German Civil Code which has adopted a century later. I start from two premises:

Firstly, the vision of the French revolution which was proclaimed in the Declaration of Human Rights, pinned down in a Constitution and later codified in the Civil Code has deeper social, cultural, economic and intellectual roots. I argue that today's conception of freedom of contract in France can best be understood as a political forward-looking concept. This goes back to French Rationalism ${ }^{47}$ and Descartes. ${ }^{48}$

${ }^{42}$ L. Miller, The Emergence of EU Contract Law - Exploring Europeanization (Oxford, University Press, 2011), who analyses in detail the struggle in the UK over the implementation of the Directive 99/44/EC on consumer sales, p. 96 et seq.

${ }^{43}$ G. Teubner, Legal Irritants: Good Faith in British Law or How Unifying Law Ends Up in New Divergencies, Modern Law Review (68) 1998, 11.

${ }^{44}$ House of Lords of 25 October 2001, The General of Fair Trading v. First National Bank plc, (2001) UKHL 52, European Review of Contract Law, Vol. 2 (2006) No. 4, 471 and Judgment, 25.11.2009, Office of Fair Trading (Respondents) v. Abbey National plc \& Others (Appellants), Michaelmas Term (2009) UKSC 6 on appeal from (2009) EWCA Civ 116; H. Kötz, Schranken der Inhaltskontrolle bei den Allgemeinen Geschäftsbedingungen der Banken: Entscheidung des britischen Supreme Court vom 25. November 2009, ZEuP 2012, 332

45 Arendt, H. (1963), On Revolution, London: Penguin Books.

${ }^{46}$ F. Wieacker, F. (1967), Privatrechtsgeschichte der Neuzeit, 2. Auflage, Göttingen, p. 343.

${ }^{47}$ For a deeper analysis, Laurence BonJour: In Defense of Pure Reason, Cambridge University Press, Cambridge, U.K. 1998; Laurence BonJour: A Rationalist Manifesto, in: Canadian Journal of Philosophy Supp. 18 (1992), S. 53-88

${ }^{48}$ See on Descartes and his methodological thinking, E. Friedell, Kulturgeschichte der Neuzeit, Die Krise der Europäischen Seele von der schwarzen Pest bis zum ersten Weltkrieg, Erste Ausgabe in drei Bänden, 1927-1931, reprint without date C.H. Beck, p. 495 et seq. 
Secondly, French society may be characterised by the tension between, on the one hand, intellectual projects guided by 'les grandes idées' - the French Constitution and the French Code - which strengthen the power of the Executive to the detriment of the power of the Judiciary, and on the other hand, the highly politicised bottom-up resistance against an excessively far reaching executive power. ${ }^{49}$

The fight over 'the Social ${ }^{50}$, the fight over regulatory intervention to protect workers in employment contracts and later the consumers in b2c contracts demonstrates that setting limits to the freedom of contract via statutory intervention is a highly political and politicised matter throughout society, subject to conflict, support or rejection.

Just as in England, the intellectual turning point can be attributed to the fading influence of scholastic thinking. Its questioning of the spirit derived from methodological scholastic constraints paved the way for a particular French rational method in philosophy. Montaigne (1533-1592) set long lasting incentives for critical reflection of all existing knowledge and values, what was later named 'Enlightenment'.

The new method to investigate the 'truth' and the concept of the truth was left to the 17th century, to Descartes who began with his Discours de la Méthode. He claimed that a particular method to acquire the truth is needed, which then allows to solve all philosophical questions. For in Descartes' philosophy 'what is true is useful' and not 'what is useful is true' like in utilitarianism. Without Descartes it is hard to understanding the particular political conception of the French Civil Code. Descartes' philosophy results in the priority of theory over practice which is the basic thesis of French intellectualism.

Once this is assumed, the link between the French political project of freedom of contract and the particularities of the French legal culture become clear. Freedom of contract is first and foremost tied to the key function of the 'reason' - 'raison' - 'Vernunft' in the French Civil Law system. The idea is that freedom of contract is more than just an exercise to maximise mutual economic benefit. There is more at stake in the communication between the parties, the commitment to a contract is the product of

a 'reasonable decision'. 'Autonomie de la volonté' is bound to the belief/assumption (Einsicht) in a higher reason, one which reaches beyond and deeper than the individual transaction. ${ }^{52}$ This is the Cartesian side of the concept of 'autonomie de la volonté. However, there is also the Rousseauean side and it is here where the political dimension of the concept of 'automomie de la volonté' is more obvious. 'Autonomie de la volonté' may not be equated with individual freedom in the meaning of German idealism. It is just the contrary, it is not inward looking it is outward looking towards society, to the embedding of 'reason' into the political environment, this is what Rousseau calls the 'volonté générale'. Without Rousseau's concept of democracy and the conviction that the people will consent to the 'volonté générale' chastened by sense/reason? (aus Einsicht) it is not possible to understand the political dimension of the 'autonomie' in the French civil code. ${ }^{53}$

\footnotetext{
${ }^{49}$ This is my own interpretation of the French development.

${ }^{50}$ See on the rise of 'The Social' and its intellectual origins D. Kennedy, (2006), 'Three Globalizations of Law and Legal Thought: 1850-2000', same author, The Rule of Law, Political Choices and Developing Common Sense both published in D. Trubek/A. Santos (eds), The New Law and Economic Development, Cambridge University Press, 2006, p. 19 and p. 95; from a German perspective although taking the French impact into account, in particular Duguit, Salleilles and Gény, F. Wieacker, Privatrechtsgeschichte der Neuzeit, loc.cit. $543 \S 28$ Der Zerfall der inneren Einheit des Privatrechts und das Sozialrecht. In that vain law has a particular social function to fulfill.

${ }^{51}$ See on Montaigne, E. Friedell, Kulturgeschichte der Neuzeit, Die Krise der Europäischen Seele von der schwarzen Pest bis zum ersten Weltkrieg, Erste Ausgabe in drei Bänden, 1927-1931, reprint without date C.H. Beck, p. 371 et seq

52 This implies the need to look for a certain substantive equivalence in the mutual contractual relations, in German 'das materielle Äquivalenzprinzip der vernunftsrechtlichen Vertragslehre' .

${ }^{53}$ I am fully aware that Rousseau differs from Descartes in his image of the person.
} 
France is also peculiar with regard to the role and function of regulatory intervention into the economy to the benefit of workers and consumers, to the overall idea of restricting the freedom of contract in commercial transactions through statutory regulation. Since mercantilist times the French state plays and claims to play a strong role in the organisation and the making of the economy. ${ }^{54}$ The economy has to follow political prerogatives in order to meet social/societal concerns or any other political requirements. What matters in our context is the strong link between the role and function of the political and the understanding of regulatory intervention. The political dimension may not necessarily result from a top down perspective, from the legislative introducing what is called in today's language social regulation, or the Executive which was and is the key actor in managing the economy of the country, the political may also emerge bottom up, from resistance in the streets against the supremacy of the state managed economy over politics.

In order to demonstrate the strong continuity of the French Rechtsbewu $\beta$ tsein, of the breadth and depth of the political in social regulation, I will again start with reference to the implementation of EU Directive 99/44/EC on consumer sales. Under strong pressure from civil lawyers and civil law doctrine, quite similar to the foregoing debate over the implementation of Directive 85/374/EEC on product liability, the French legislator decided not to integrate the rules on consumer protection into the Civil Code but to place the respective articles in the Code de la Consommation. ${ }^{55}$ This strategy saved the integrity of the Civil Code, as an 'eternal' political project, which might be regarded as an integral part of the French 'identity'. ${ }^{56}$ However, there is one notable difference to the English method of transposition. Contrary to the UK, France adopted a Code de la Consommation which was originally designed according to a political model, a blueprint which similar to the Civil Code could guide the development in Europe of a consistent body of consumer law rules. ${ }^{57}$

Contrary to most other Member States in the EU, the consumer movement in France bore a strong political dimension, at least in the 1970s and 1980s, which largely derived from politicisation through integrating consumer policy into politics. Trade unions in France are tied to the different left wing parties. Each of them had to leave their footprint on the then new policy. ${ }^{58}$ It is only through the EU

\footnotetext{
${ }^{54}$ K. Pribam, Geschichte des ökonomischen Denkens, Erster Band, Suhrkamp Taschenbuch Wissenschaft Frankfurt, $1998,7$. Kapitel, Cartesianische Wirtschaftslehre, p. 194. German translation of A History of Economic Reasoning, John Hopkins University Press 1983; C. Heywood, The Development of the French Economy, 1750-1914, 1995.

${ }^{55}$ L. Miller, The Emergence of European Private law, loc. cit., who reconstructs the political fights over the correct way to implement the directive in the French legal system, in particular p. 90 et seq.

${ }^{56}$ It suffices to study the strong reaction of French scholars against the idea of European Civil Code; Yves Leqeutte, Quelques remarques à propos du projet de code civil européen de Monsieur von Bar, Recueil LeDalloz 2002, 2202-14; Bénedicte Fauvarque-Cosson, Faut-il un code civil européen?, Revue Trimestrielle De Droit Civil 2002, 463; also, Droit européen des contracts: première réaction au plan dáction de la Commission, Receuil le Dalloz 2003, 1171; Ph. Malinvaud, Réponse-hors délai- à la Commission européene: à propos d'un code européen des contracts, Receuil La Dalloz 2002, 2542-51; Jean Heut, Nous faut-il un 'euro' droit civil? Receuil La Dalloz 2002, 2611-14; Wolfgang Wurmnest, Common Core, Grundregeln, Kodifikationsentwürfe, Acquis-Grundsätze - Ansätze internationaler Wissenschaftlergruppen zur Privatrechtsvereinheitlichung in Europa, ZEuP 2003, 714 et seq. Christian Joerges, Der Europäisierungsprozess als Herausforderung des Privatrechts: Plädoyer für eine neue Rechtsdisziplin, in: Andreas Furrer (ed.), Europäisches Privatrecht im wissenschaftlichen Diskurs, 2006, 133, 142 interprets the conflict between the German professorial model of the BGB and the democratic tradition of the Code Civil.
}

Whether or not the French Civil Code would pass the 'identity test under the Lisbon Treaty is another story, see H.-W. Micklitz, German Constitutional Court (Bundesverfassungsgericht BVerfG) 2 BvE 2/08, 30.6.2009 - Organstreit proceedings between members of the German Parliament and the Federal Government, ERCL 2011, 528-546.

${ }^{57}$ J. Calais-Auloy, Commission de la Refonte, Le Droit de la Consommation en France, 1981.

${ }^{58}$ This might explain why attempts to build links between labour law and consumer law were particulary strong in France (to some extent in Italy and only marginal in Germany), M. Mialle, Introduction critique au Droit, 1976; E. Roppo, Verbraucherschutz und Klassentheorie, Demokratie und Recht 1976, 109; K. Tonner, Verbraucherschutz und Klaasentheorie - Erwiderung auf Enzo Roppo, Demokratie und Recht 1976, 241; same author, Verbraucherschutz als gewerkschaftliche Aufgabe, Zeitschrift für Verbraucherpolitik 1979, 252. 
taking over consumer policy in the second half of the 1980s after the Single European Act that consumer policy became de-politicised in France.

\section{The German Model - Liberal and Authoritarian/Paternalistic}

The German Civil Code is a hundred years younger than the French Civil Code. In the aftermath of the Congress of Vienna, 1815, the scattered German regions (kingdoms, counties (earldoms), regions) failed to unite into a German state, under its own constitution. It took until 1871 before Germany managed, under the regime of the Prussian king/emperor and his chancellor Bismarck, to adopt a constitution and a further thirty years before the Bürgerliches Gesetzbuch was enacted. I build my arguments around two major guiding assumptions:

Firstly, there is a direct line from Kant to Savigny to the formal rationality of the private law system (Weber) which serves to constitute the capitalist society. The Kantian philosophy inspired Savigny in the foundation of the so-called 'Historische Schule,' which gained a dominating influence during the 19th century and which, remarkably, continues to gain influence even after the fall of the wall in $1989 .^{59}$ It has created a particular way of thinking, which favoured the rejection of 'The Social' into the 'pure' private law system. Social issues, social regulations were outsourced via a technocratic decision to special private law legislation outside the BGB, although adopted 100 years later even beyond the more integrative approach of the French Code Civil. ${ }^{60}$ This divide gives the German BGB a particular ideological outlook, maintaining and defending an early $19^{\text {th }}$ century bourgeois model of society and economy against the rising political and social transformations brought about by the industrial and the labour movement. ${ }^{61}$

age

Secondly, there is the link between Fichte, Hegel, Thibaut, German idealism, and legal naturalism, as expressed in Jhering, v. Gierke, Ehrlich, Weber and Kantorowicz, wherein national ideals were tied to social ideals of a society and a nation. ${ }^{62}$ Such a vision can hardly be connected to the authoritarian Prussian state that accepts the responsibility for guaranteeing social protection to workers (1883 health insurance, 1884 accident insurance) only as a means to compensate workers from their exclusion from political participation (so called Sozialistengesetze 1978). The German version of legal naturalism favours an instrumental use of social regulation, ${ }^{63}$ though carefully avoiding and downplaying the political dimension inherent in 'The Social'.

The intellectual quarrel of the two German law professors, Thibaut and Savigny over the value of a codified German Civil Code is still paradigmatic for the tensions in the German legal system:

${ }^{59}$ R. Zimmermann, «Savigny's Legacy: Legal History, Comparative Law, and the Emergence of a European Science. », (1996) Law Quarterly Review, 576-605 and the critique against the European private law codification project which is inspired of and based on the destruction of the common philosophical ground of private law in the civil and common law system, see Horst Eidenmüller, Florian Faust, Hans Christoph Grigoleit, Nils Jansen, Gerhard Wagner, Reinhard Zimmermann, The Common Frame of Reference for European Private Law - Policy Choices and Codification Problems, Oxford Journal of Legal Studies 2008, 659 - 708

${ }^{60}$ Both the French Code Civil and the German Bürgerliches Gesetzbuch covered tenant law. However, in France tenant law always remained an integral part of the civil code, whereas in Germany tenant law became a legal field in itself outsourced in special acts and only partially integrated in the Bürgerliches Gesetzgebuch via the act on modernization of the law of obligations (Schuldrechtsmodernisierungsgesetz) in 2002, for details on the development of tenant law in Europe, see Ch. Schmid/J.Dinse, The European Dimension of Residential Tenancy Law, in: European Review of Contract Law, 2013, S. $201-220$

${ }^{61}$ There is a link between the late indudustrialisation relative to the UK., the labour movement and the Bismarckian reaction.

${ }^{62}$ F. Wieacker, Privatrechtsgeschichte der Neuzeit, loc. cit. 570 Most of the legal auxiliary sciences such as criminology, Rechtstatsachenforschung as well as legal sociology have their origin in legal naturalism and in the Freirechtsschule.

${ }^{63}$ Instructive Hermann U. Kantorowicz, who attacks Savigny's influence on the construction of the Civil Code and on what I call here Rechtsbewußtsein, Was ist uns Savigny, Recht und Wirtschaft Band 1 1911, 47 et seq. and 76 and seq. 
Thibaut fighting in Heidelberg enthusiastically - inspired by German Idealism and 'les grandes idées' of the French revolution - for a genuine German Code, Savigny fighting brilliantly (but not enthusiastically) for the maintenance of the old Roman law. ${ }^{64}$ Law-making in the Germany of the early 19th century was understood as an academic exercise, quite contrary to the democratic discussion that surrounded the adoption and distribution of the French Civil Code, a heritage which can be felt until today. ${ }^{65}$

The outcome was a civil code lacking the required 'socialist oil', ${ }^{66}$ a defect which was remedied by the judges/judge-made law in the 20th century and by the legislator through the adoption of numerous special laws, which overcame Savigny's resistance but which was inspired by his way of thinking.

German legal culture may be characterised by two leading components, on the one hand the liberal dimension, Germany shares with England, - enshrined in commercial freedom to contract - on the other the political dimension Germany shares with France - enshrined in the much stronger commitment at least in relation to England to 'The Social' ${ }^{67}$ The English inspiration dates back to the merging of the German Länder under a tight Prussian grip which triggered the industrial revolution. It led to an amazing boost for the economy. Here the predominance of the market and a sense of English pragmatism can be felt. The German state, however, is not the liberal enabling state in the AngloSaxon sense. The German state is rooted in the authoritarian heritage of pre-democratic times. Here the state is seen as the key regulator meant and in charge to realise not only economic but also political objectives, which brings German legal culture nearer to its French counterpart. Contrary to France, where the political also bears a strong bottom-up dimension, in Germany the political dimension is always linked to expectations set by the citizens of the state. The early Bismarckian regulatory state and the post-World War II welfare state bears until today elements of this authoritarian care-taking different from England due to the strong interventionist side, and different from France due to the lack of an open political discourse. The tension between the two poles the liberal and the authoritarian explains why in Germany political debates so easily turn into ideological conflicts, just as it was between Thibaut and Savigny.

What does this mean for the German variant of freedom of contract, - intellectual history provides us with the term 'private autonomy' (Privatautonomie) - and the limitation/restriction of freedom of contract/private autonomy via statutory regulation? Private autonomy centres on the individual, who is the individual, the reasonable Cartesian French person/citizen?, the utilitarian Englishman or the idealistic Kantian/Hegelian subject? Through what can he/she bind him/herself - this is the key question in German legal theory, not the commercial transaction, not freedom of contract, not the common law of contracts or the droit des obligations. The conceptual difference is visible in the comparison between the common law and the Code Civil. Only the German BGB contains a 'general part'

einen Allgemeinen Teil, which does not only precede the law of contract, but also family law and the law of succession. The General Part holds the German private law systems as enshrined into the BGB together. Its configuration outside Germany yields irritation and uncertainty (what is a juridical act? -

${ }^{64}$ Thibaut, A.F.J. and F.C. v Savigny [1973] (2002), Ihre programmatischen Schriften, mit einer Einführung von Hans Hattenhauer, München.

${ }^{65}$ See R. Zimmermann, Consumer Contract Law: The German Experience, Legal Current Problems 2005, p. 415; H. Schepel, Professorenrecht? The Field of European Private Law. in: Berg, P.A.J.van den (ed). Lawyer's Circles Lawyers and European Legal Integration. Elsevier Reed, 2004, pp. 115 ; Kiesow, Rechtswissenschaft - was ist das? JZ 2010, 585 p. 586.

${ }^{66}$ O. v. Gierke, Die soziale Aufgabe des Privatrechts, 1889, p. 13; deeper Th. Repgen, Die soziale Aufgabe des Privatrechts: eine Grundfrage in Wissenschaft und Kodifikation am Ende des 19. Jahrhunderts, Mohr Siebeck, 2001.

${ }^{67}$ G. Brüggemeier, Entwicklung des Rechts im Organisierten Kapitalismus, Band 1: Von der Grüderzeit zur Weimarer Republik, 1977, Band 2: Vom Faschismus bis zur Gegenwart, Syndikat Verlag Berlin, 1979. 
Ein Rechtsgeschäft $\left.?^{68}\right)$. The key to understanding the idealistic German concept of private autonomy is its grounding in the so-called Willenstheorie (the will theory ${ }^{69}$ ), the individual is bound through his/her will, not through his or her declaration (Erklärung). It is true that already the Prussian legislator in the BGB introduced corrections which have been amplified by the judiciary in the $20^{\text {th }}$ century. Idealistic thinking enshrined in the concept of private autonomy is still alive, it has been taken up by the Freiburg school, ordo-liberalism and the private law society. ${ }^{70}$ Its counterpart, the resistance against restrictions more often than not bears a strong ideological bias which is outweighed by intense legislative activities in the $20^{\text {th }}$ century to the benefit of the weaker parties to contracts.

Again, I will use Directive 99/44/EC as a blueprint to explain the continuity of the German Rechtsbewusstsein, the tension between the liberal and the authoritarian side of 'freedom of contract'. In 2002, in the shadow of the so-called modernisation of German contract law (SchuldrechtsModernisierungsgesetz), the executive, i.e. the Ministry of Justice, used the expiry of the two years implementation period to realise the 20 years long pending project of a revision of the German Civil Code thereby 'smuggling' the bulk of consumer contract law rules into the German Civil Code, perhaps not in an authoritarian but in a paternalistic move. ${ }^{71}$ The academic attention focused nearly entirely on the proposed revision of the prescription rules, on Leistungsstörungsrecht (interference with or impairment of the performance of an obligation). The revision has been performed as a technical bureaucratic exercise. ${ }^{72}$ Pragmatism might have guided German scholars to accept the development of a new sales law, as a common pattern for $b 2 b$ and $b 2 c$ relations, but contrary to France and the Netherlands there was no deeper political discussion in the open democratic fora, in particular not on the possible role of consumer law as an integral part of the civil code. Until today, consumer law has remained an alien part in the German BGB. The integration of the 'Social' has not led to an overall

re-thinking of the foundations of the German BGB. The two parts stand together apart, each enshrined in their very particular intellectual history. ${ }^{73}$

${ }^{68}$ As documented in the Academic Draft Common Frame of Reference which contains such a general part in compliance with the German BGB.

${ }^{69}$ Extremely helpful because of the combination of European legal with American legal throught, D. Kennedy, From the Will Theory to the Principle of Private Autonomy: Lon Fuller's 'Consideration and Form', online at http://duncankennedy.net/documents/From\%20the\%20Will\%20Theory\%20to\%20the\%20Principle\%20of\%20Private\%2 0Autonomy.pdf

${ }^{70}$ It suffices to read E.-J. Mestmäcker's reply to the critics of law and economics against ordo-liberalism, A Legal Theory without Law. Posner v Hayek on Economic Analysis of Law Mohr (Siebeck), Beiträge zur Ordnungstheorie und Ordnungspolitik Band 174, Tübingen 2007.

${ }^{71}$ There is a deeper discussion needed on the difference between (Prussian) authoritarianism and (post Second World War) German paternalism. A starting point on the distinction should be A. De Tocqueville, Democracy in the America, originally in French 1835/1840 two volumes, See Chapter VI, "Above this race of men stands an immense and tutelary power, which takes upon itself alone to secure their gratifications and to watch over their fate. That power is absolute, minute, regular, provident, and mild. It would be like the authority of a parent if, like that authority, its object was to prepare men for manhood; but it seeks, on the contrary, to keep them in perpetual childhood: it is well content that the people should rejoice, provided they think of nothing but rejoicing. For their happiness such a government willingly labors, but it chooses to be the sole agent and the only arbiter of that happiness; it provides for their security, foresees and supplies their necessities, facilitates their pleasures, manages their principal concerns, directs their industry, regulates the descent of property, and subdivides their inheritances: what remains, but to spare them all the care of thinking and all the trouble of living?" http://xroads.virginia.edu/ Hyper/detoc/ch4_06.htm

72 See e.g. Lorenz, 5 Jahre „neues“ Schuldrecht im Spiegel der Rechtsprechung, NJW 2007, p. 1, the University of Munich organised a conference under the heading of , 10 Jahre Schuldrechtsmodernisierung' (10 years modernisation of the law of obligations). The results are not yet published, http://lorenz.userweb.mwn.de/tagung2012.pdf

${ }^{73}$ H.-W. Micklitz, Brauchen Konsumenten und Unternehmen eine neue Architektur des Verbraucherrechts? Gut-achten A zum 69. Juristentag, C.H. Beck München, 129 Seiten, 2012; in English Do Consumers and Business need a New Architecture for Consumer Law? A Thought Provoking Impulse, Yearbook of European Law, Vol. 32, No. 1 (2013), pp. 266-367. 


\section{The European Model - Enabling and Restricting}

The 'European legal order' and the 'European constitutional charter' ${ }^{74}$ has yielded, over the last sixty years, a genuine model of freedom of contract, a model which establishes freedom of contract to the benefit of the participants in an ever growing Internal Market, but at the same time setting boundaries to the established freedom. ${ }^{75}$ How come, how is it possible that the EU is able to generate a different model? I am not so much interested in whether the emerging European model should be understood as some kind of reaction to the globalization of markets, a Polanyian variant of the transformation of the economy. ${ }^{76}$ My focus is on the intellectual history of the European legal order that underpins Europe and more closely the European Union. The two - Europe and the European Union - have to be kept separated, although they are intertwined as will have to be demonstrated.

Perspective matters. Seen from the outside, in particular through the lenses of US research, Europe is treated as a rather homogenous whole. It might suffice to recall the writings of James Whitman ${ }^{77}$ on US consumerism vs EU producerism or Daniel Kelemen ${ }^{78}$ on Eurolegalism. There is not much difference made between south and north, east and west, the European Union and the European Council, there is no discussion on where Europe ends, it is just Europe in contrast to the United States, Europe often implicitly equated with the European Union. This kind of thinking has been triggered and promoted through the 'Integration through Law' project by M. Cappelletti/M. Seccombe/J. Weiler $^{79}$ aimed at comparing the constitutional architecture of the then European Economic Community and the United States. The deep imprint of thinking in EU/US contrast (the old and the new world at a time) is easily to realize/understand?. Each European might come to similar conclusions provided he or she spends a couple of months in the United States, or in South East Asia. I have never had a stronger feeling of 'being European' than when I returned to 'Europe' after six months of a research sojourn at the University of Michigan, Ann Arbor. So there must be something that is genuinely 'European' in the national legal systems despite all the bifurcations and differences of the 'shared' intellectual history. But what exactly is it? Is it the deeper cultural layer, F. Wieacker, P. Grossi and H. Coing, ${ }^{80}$ are referring to in their efforts to rebuild Europe after the Second World War? Or is this perception more closely and more narrowly linked to the European Union, which has its own history after 60 years of existence? ${ }^{81}$ But what kind of history is it? Is the European Union developing its own intellectual history? How is the EU intellectual history linked to those European countries, which do not belong to the EU?

My research question is modest, but complicated enough. I want to look at the interaction between the different legal, political and philosophical foundations for the time period I investigated in the

\footnotetext{
${ }^{74}$ Walker, N. (2006), 'Big 'C' or Small ‘c’?’, European Law Journal, 12 (1), 12-14.

${ }^{75}$ G. Comparato/H.-W. Micklitz, Regulated Autonomy between Market Freedoms and Fundamental Rights in the Case Law of the CJEU, in General Principles of EU Law and European Private Law Edited by Ulf Bernitz Xavier/Groussot/Felix Schulyok, Ashgate 2013, 121-154; in same direction N. Reich, General Principles of EU Civil Law, 2013.

${ }^{76}$ K. Polanyi, The Great Transformation, 1944; Ch. Joerges/J. Falke (eds.), Karl Polanyi - Globalisation and the Potential of Law in Transnational Markets, 2011.

77 J. Whitman, Consumerism Versus Producerism: A Study in Comparative Law, 117 Yale L.J. 407 online http://digitalcommons.law.yale.edu/cgi/viewcontent.cgi?article=1643\&context=fss_papers

${ }^{78}$ D. Kelemen, Eurolegalism, The Transformation of Law and Regulation, 2013.

${ }^{79}$ M. Cappelletti/M. Seccombe/J. Weiler, Integration Through Law: Europe and the American Federal Experience, M. Cappelletti/M. Seccombe/J. Weiler (eds.), Integration Through Law, Volume 1, Book 1, 1986, 3-68; D. Augenstein (ed.) 'Integration through Law' Revisited: The Making of the European Polity, Ashgate 2011.

80 K. Tuori, Reinventing the Foundations of European Legal Culture 1934-1964, ERC Start Grant 2013-2018; http://blogs.helsinki.fi/found-law/researchers/kaius-tuori/

81 See the Historical Archives of the European Union at the European University Institute, http://www.eui.eu/Research/HistoricalArchivesOfEU/AbouttheHistoricalArchives/Index.aspx
} 
intellectual history of the UK, France and Germany. Is it possible and feasible to find and identify a joint deeper layer, one, which is more concrete than the reference to the 'common European legal culture'.

Is there a common denominator of English Utilitarianism, French Rationalism and German Idealism, which is mirrored in the conception of freedom of contract and its statutory limitation? Is there a baseline between 'English liberal and pragmatic' - 'French rational and political' - 'German liberal and authoritarian'? To what extent did the intellectual crossover unfold a mutual impact in the three nations? Those who stress the common cultural layer insist on the intellectual exchange between the great minds behind the concepts of empiricism, utilitarianism, rationalism, enlightenment and idealism. For centuries European intellectuals shared a common language 'Latin', which only gradually vanished in the $17^{\text {th }}, 18^{\text {th }}$ and $19^{\text {th }}$ century. But it cannot be language alone. Let me take an example from private law history to make my point. In the late $19^{\text {th }}$ early $20^{\text {th }}$ century leading private lawyers from all over Europe and the United States were involved in intellectual exchange, but they all wrote in their respective languages. ${ }^{82}$ It seems as if the intellectual exchange was much more intense hundred years ago or hundreds years ago - than it is today in a world, where the English language dominates the intellectual discourse and where non-English contributions to the intellectual history are not perceived any more.

Wieacker ${ }^{83}$ might be referred to as one of the few who looks behind the three big intellectual historical strains condensing the common European legal culture that unites the private law 'in der Neuzeit ${ }^{84}$ in three 'invariables' (1) personalism from, where there is a straight forward link to the key role of the individual, autonomy and freedom in private law. However without guidance on the differences; (2) legalism - decisions are bound to the rule of law and (3) European intellectualism 'driving European legal thinking in the direction of thematisation, conceptualization, and contradiction-free consistency of empirical legal materials'. However, is this correct? Is the revitalization of the common European legal culture after the Second World War not very much guided by the political purpose it had to fulfill? Has the common European legal culture to be regarded as an attempt to rewrite legal history? I fear, the question is too big and too far-reaching to be answered in this paper. ${ }^{85}$ The debate on the possible legal philosophical foundations of Europe ${ }^{86}$ let alone the foundations of European private law $^{87}$ is just about to start. The handbook edited by Julie Dickson and Pavlos Eleftheriadis ${ }^{88}$ on the 'philosophical foundations of EU law' mainly focuses on European constitutional theory, European private law and European private law theory does not form part of that project. ${ }^{89}$

\footnotetext{
${ }^{82}$ For instance the exchange between German and French legal theorists, Demogue, La Notion de Sujet De Droit, Revue Trimestrielle de Droit Civil 1909, 611-655, Josserand, L'évolution de la responsabilité (conférence donnée aux Facultés de Droit de Lisbonne, de Coimbre, de Belgrade, de Bucarest, d'Orades, de Bruxells, à l'institut français de Madrid, aux centres juridiques de L'Institut des Hautes Études marocaines à Rabat et á Casablanca) Évolutions et Actualités Conférences de Droit Civil, Receuil Sirey, Paris, 1936, 29-51.

${ }^{83}$ European legal cultures, 19 et seq., 25.

${ }^{84}$ This is the title of his masterpiece, Privatrechtsgeschichte der Neuzeit, translated into English by Tony Weir

${ }^{85}$ For instance F. Heer, The Intellectual History of Europe, 1968; R.C. van Canegem, European Law in the past and the future: unity and diversity over two millennia, Cambridge University Press, 2002; W. Kaiser, Christian democracy and the origins of European Union, 2007 and the research network on the transformative power of Europe, http://www.polsoz.fu-berlin.de/en/v/transformeurope/publications/index.html

${ }^{86}$ J. Whitman, The Legacy of Roman Law in the German Romantic Era: Historical Vision and Legal Change (Princeton Legacy Library), 2014

${ }^{87}$ R. Brownsword/H.-W. Micklitz/L. Niglia/St. Weatherill (eds.), Foundations of European Private Law, Hart Publishing 2011.

${ }^{88}$ Julie Dickson and Pavlos Eleftheriadis (eds.), Philosophical Foundations of European Union Law, Oxford University Press, 2012.

${ }^{89}$ Apparently in the OUP series where also Dickson/Eleftheriadis appeared there is project under way on the philosophical foundations of private law.
} 
More promising for getting an understanding of the European model of freedom of contract - but also much more modest - is to look at the intellectual history (constitutional history?) of the European Union. This requires a big jump from the $17^{\text {th }}-18^{\text {th }}-19^{\text {th }}$ century into the post-war period, the launching of the European Economic Community, re-constituted first as the European Community and then the European Union. F. Wieacker, P. Grossi, H. Coing - the academic side, J. Monnet, R. Schuman, de Gasperi, de Gaulle, $K$ Adenauer - the political side, all advocated for the revitalization and the reinvigoration

a common European culture such as to enable a peaceful and prosperous future for the European peoples. Peace through economic integration this was the order of the day. In 1986, the Single European Act added social integration to the new European legal order. ${ }^{90}$

Economic integration of the EU is based on the four freedoms and competition. In particular German academics in the ordo-liberal tradition have argued that private autonomy is enshrined into the four freedoms. ${ }^{91}$ Economic integration aims at 'enabling', at paving the way for private entrepreneurship in the ever bigger first common and then European market. Behind the abundant case-law of the ECJ on the four freedoms there is more often than not a contractual dispute, one party to the contract is seeking access to the market and is barred by national statutory regulation. ${ }^{92}$ Private autonomy then gets

a different meaning, it is bound to transborder business, to European economic integration. The European variant is functional and instrumental.

Social regulation in European private law is very much focused on consumer protection. ${ }^{93}$ The tone is still set by the famous Sutherland report. Consumers and consumer protection rules are needed to complete the Internal Market (the 1986 program behind the Single European Act). Put differently, there is a price to pay for the Completion of the Internal Market and this price is the adoption of minimum $^{94}$ social (protection) standards. The overall philosophy is enshrined in the wording of Article 114 TFEU (formerly Article $95 \mathrm{EC}$, Article 100a respectively), adoption measures to complete the Internal Market in realizing social protection standards. Since the mid-1980s - several consumer protection rules and also labour protection rules were already adopted in the late 1970s or the early 1980s under the unanimity principle, - the enabling and the framing of autonomy go hand-in-hand, although realized with a certain time lag. The broadening of the economic freedoms, very much along the line of the common law understanding of freedom of contract, precedes the development of protective standards that limit the freedom of contract, mainly through binding legal standards.

The development is by no means limited to the field of traditional private law, contract law and consumer protection or employment contracts and labour protection. European private law is 'regulatory' by nature, as the European Union is and remains a project under constant construction.

${ }^{90}$ So much has been written on this. Again it is hard to mention names, but it seems that the writings of Fritz Scharpf, Governing in Europe: Effective and democratic, 1999 - on the relationship between the two have been particularly influential.

${ }^{91}$ S. Grundmann, The Concept of the Private Law Society, After 50 Years of European Law and European Business Law, European Review of Private Law 16 (2008), 553. A nice account of the European economic constitution in its influence on (European) private law is given by S. Frerichs/T. Juutilainen, Rome under Seven Hills? An Archeology of European Private Law, Legal Studies Research Paper Series No. 32; forthcoming in St. Börner/M. Eigmüller (eds.): European Integration, Processes of Change and the national Experience, Palgrave, available online http://papers.ssrn.com/sol3/papers.cfm?abstract_id=2465873

${ }^{92}$ G. Davies, 000 in St. Weatherill/D. Leczykiewicz (eds.), The Involvement of EU Law in Private Law Relationships, Hart Publishing 2013.

${ }^{93}$ See St. Weatherill, loc. cit. and H.-W. Micklitz/N. Reich/P. Rott/K. Tonner, European Consumer Law, Intersentia 2nd edition, 2014

94 The European Commission has made an enormous effort after 2000 to transform the minimum standards into maximum standards, but largely failed, H.-W. Micklitz/N. Reich, Crónica de una muerte anunciada: The Commission Proposal for a 'Directive on Consumer Rights', Common Market Law Review, 47 (2009) 471-519 
For its realization legal rules remain a key instrument. The most prominent field of action outside and beyond traditional private law and even beyond traditional fields of social regulation (consumer and labour protection) has been the so-called regulated markets. The liberalization and privatization policy triggered by the Single European Act in telecom, energy, postal services, transport and financial services, the dismantling of former state monopolies, more generally the political decision to establish markets where there were none, this policy made the link between enabling freedom of contract whilst at the same time setting boundaries to that freedom even more feasible. Enabling and restricting are the two parameters that characterize the European model of freedom of contract.

\section{Stand and stare}

Provided my analysis contains an element of truth - what I do hope - what is the added value of this finding for our understanding of 'freedom of contract' and even more so for the communication between lawyers across legal cultures and traditions, just like in our Academy for International Commercial and Consumer Law? First and foremost it means 'Stand and Stare'95 - trying to gain distance to our subject of analysis, to our own cultural roots and traditions. Esser's book on preconceptions cannot be read as a manual to bridge the gap between our preconceptions and the law in the books and the law in action. I understand it more as a message of caution and modesty.

'Stand and stare', however, is no more than just a first step. I do not want to argue that our legal cultures and traditions are set in stone and that there is no room for mutual learning and for change. Indeed, there is something like an emerging European legal culture, certainly in key areas of private $\mathrm{law}^{96}$ - some would argue it is enshrined ever since the ius commune - there exists even an emerging culture

of transnational law ${ }^{97}$ - now gaining ever stronger attention in a refocused understanding and design of comparative and transnational (legal) history. ${ }^{98}$ I fear, however, that we are approaching a divided legal world, a national one, connected to the respective state, the national legal order, the territory and the language and a transnational one, where there is a chance for deepening of our understanding of the 'many faces of freedom of contract', for learning from each other and for developing even a common cultural ground. ${ }^{99}$

\footnotetext{
${ }^{95}$ R. Brownsword, The Theoretical Foundations of European Private Law: A time to Stand and State in R. Brownsword/H.W. Micklitz/L. Niglia/St. Weatherill (eds.), Foundations of European Private Law, Hart Publishing 2011, 159.

${ }^{96}$ G. Helleringer/K. Purnhagen (eds.), Towards a European Legal Culture, C.H. Beck, Hart, Nomos 2014

${ }^{97}$ K. Tuori, Transnational Law: on legal hybrids and legal perspectivism in M. Maduro/K. Tuori/S. Sankari (eds.), Transnational Law, Rethinking European Law and Legal Thinking, Cambridge University Press, 2014, at 11.

${ }^{98}$ Th. Duve, European Legal History - Global Perspectives Working paper for the Colloquium 'European Normativity Global Historical Perspectives' (Max-Planck-Institute, September, 2nd-4th, 2013), Working paper 2013/06.

${ }^{99}$ H.-W. Micklitz, An Essay on the Bifurcation of Legal Education - National vs Transnational, to be published Chinese University of Hong Kong, 2014.
} 



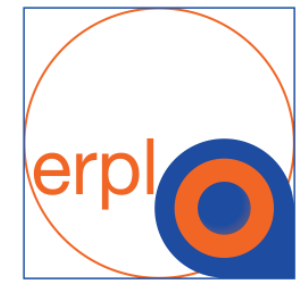

European Research Council

Established by the European Commission

This EUI Working Paper is published in the framework of an ERC-funded project hosted at the European University Institute. 